\title{
Impact of Feeding on Olive Oil with Thyme on Health Status of First Generation of Rat
}

\author{
Amany A. Salem ", Hayam A. Elsawy, Salwa S. Gabal \\ Special Food and Nutrition Department, Food Technology Research Institute, Agriculture Research Center, Ministry of Agriculture, Giza, \\ Egypt
}

Email address:

Amanysalem2013@gmail.com (A. A. Salem)

\section{To cite this article:}

Amany A. Salem, Hayam A. Elsawy, Salwa S. Gabal. Impact of Feeding on Olive Oil with Thyme on Health Status of First Generation of Rat. International Journal of Nutrition and Food Sciences. Vol. 4, No. 5, 2015, pp. 509-517. doi: 10.11648/j.ijnfs.20150405.11

\begin{abstract}
This study aimed to evaluate the effect of feeding rats on virgin olive oil (VOO) and extra virgin olive oil (EVOO) with or without thyme powder on health status of their first generation. Outcome of pregnancy in each group (pregnant and lactating rats fed on olive oils and thyme which randomly divided into 15 groups) were divided into 2 subgroups (male and female) and feeding a month later (till 8 weeks aged). The babies were weighted, blood was collected and scarified. Organs were removed and weighted. Biochemical assays and bone measurements were evaluated. Generally, the groups fed on VOO had a high number of babies, a low body weight and high of liver weight compared to groups fed on EVOO. Total cholesterol (TC), LDL-C and risk factor of male fed on olive oils (100\%) had higher values than groups fed on olive oils (50\%). Female groups showed observed that, which groups fed on olive oils (100\%) had higher of TC, LDL-C and risk factor than groups fed on $(50 \%)$. Creatinine and urea were increased in male rats fed on olive oils while decreased in the female rats compared to control group. Male groups fed on VOO and thyme were higher of AST, ALT and ALP than groups fed on EVOO. Concerning female babies, there are a high differences between groups. In groups (male and female) were high levels of $\mathrm{Ca}$ and $\mathrm{P}$ content of bone were observed in rats fed on VOO and thyme leaves powder compared to groups fed on EVOO and thyme powder diets. In conclusion, the feeding on olive oils (VOO and EVOO) with or without thyme leaves powder diets caused to increasing of fertility, improved lipid profile and increasing $\mathrm{Ca}$ and $\mathrm{P}$ of bone contents.
\end{abstract}

Keywords: Virgin Olive Oil, Extra Virgin Olive Oil, Thyme Leaves Powder, Rats, Biochemical Assays, Bone Measurements

\section{Introduction}

The nutritional condition during pregnancy influence in utero and fetal growth and disease in adulthood [1]. Few studies are conducted on the long term effect of excess nutrition during pregnancy or lactation on obesity development in offspring [2]. The epidemic of obesity and childhood disease in development country related partly to the association between prenatal nutrition and postnatal food consumption [3]. Some studies investigated the role of maternal rich diet on fetal development [4]. The maternal obesity has a greater influence to increase the risk of disease in their offspring childhood [5].In addition to their pregnancy complication [6] and it documented a problem in human population with trans generation effect [7].

Virgin olive oil is a product widely produced and consumed throughout the ages in all over the word and is highly appreciated for its delicious taste and aroma, as well as for its nutritional properties [8]. Olive oil is established to have a higher content of unsaturated fatty acids and has been widely recommended to be superior to other oils in maintenance of health, although no detailed comparative study has been reported on its efficacy in humans or animals [9]. Olive oil is considered a healthy product because of its constituents, which include oleic acid and other unsaturated fatty acids; in addition to traces of squalence and sterols. There is a considerable data demonstrating that the consumption of olive oil is beneficial to cardiovascular health; specifically it has a favorable effect on cholesterol regulation and LDL cholesterol oxidation. It has also been shown to have antiinflammatory, antithrombotic, antihypertensive and 
vasodilator effects in both animals and human [10].

Accordingly, Youdin and Deans [11] assess whether dietary supplementation of thyme oil could address the unfavorable antioxidant-pro-oxidant balance that occurs with age. They found significant declines in the superoxide dismutase (SOD) activities in the liver and heart of the old rats, although kidney showed no decline. Liver glutathione peroxidase (GSH-Px) activity was found to have increased significantly in old rats, while a significant decrease was observed in kidney.

Herbs, aromatic plants and spices are ingredients that could be used for the production of flavored olive oils. It is well known that herbs maintain the nutritional value of the food, enhance the keeping qualities of food products and increase their shelf life [12]. While, Ayadi et al., [13] concluded that the incorporation of some Mediterranean aromatic plants to improve thermal resistance and stability.

Accordingly, El-Ghousein and Al-Beitowi [14] reported that the effect of dietary thyme in the chicken dieton serum level of glucose, total protein and globulins were significantly increased. Meanwhile, serum triglycerides and cholesterol were significantly decreased.

The present investigation aimed to evaluate the effect of feeding on olive oil and thyme on health status of first generation of rat.

\section{Materials and Methods}

\subsection{Materials}

Virgin olive oil (Olea europaea L.) VOO was purchased from the privet sector (peroxide value $=0.05 \mathrm{meq} / \mathrm{kg}$ and acidity $<0.01 \%$ ) at Sadat City, Egypt. The extra virgin olive oil (EVOO) was obtained from Food Technology Research Institute, Agriculture Research Center ARC, Giza, Egypt (peroxide value and acidity were $0.36 \mathrm{meq} / \mathrm{kg}$ and $<0.01 \%$ ). Thyme leaves (Thymus vulgaris) was obtained from Horticulture Research Institute, Agriculture Research Center ARC, Giza, Egypt. Casein, vitamins, minerals, cellulose, and choline were purchased from El-Gomhoria Company for Drug, Chemicals and Medical Instruments, Cairo, Egypt. Starch and corn oil were purchased from local market, Giza, Egypt. Kits used to determine serum total cholesterol (TC), triglycerides (TG), high density lipoprotein cholesterol (HDL), urea, creatinine, alanine Aminotransferase (ALT), aspartate Aminotransferase (AST) and alkaline phosphatase (ALP) were punched from Gamma-Tread Company, Cairo Egypt.

\subsection{Biological Experiment}

The basal diet consisted of casein $(20 \%$; protein $\geq 85 \%)$, wood cellulose $(5 \%)$, vitamin mixture $(1 \%)$, salt mixture $(3.5 \%)$ and corn oil $(10 \%)$. The ingredients of the basal diet were completed to $100 \mathrm{~g}$ with corn starch. The basal diet formulation was performed according to Reeves et al., [15].

Sixty adult Sprague-Dawely female rats (weight 113$123 \mathrm{~g}$ ) were purchased from the lab. of Animal Department of House in Ophthalmology Research Institute Giza, Egypt. The animals were housed in well aerated cages under hygienic condition $\left(22 \pm 2^{\circ} \mathrm{C}\right.$ and $40-60$ Relative humidity) and fed basal diet, for one week as adaptation period. After that the rats were randomly divided into 15 group $(n=4)$ according to the following experimental diets as shown in Table (1), feeding a month before mating and carried out using one male to two females. The pregnant rats were left to delivery and lactating their babies. Then, after the lactation period ( 4 weeks) the babies were divided into 2 subgroups male and female. Each subgroup (both male and female) contained 6 rats of babies (outcome of pregnancy) which were choose randomly and feeding on olive oils and thyme diets for one month later (till 8 weeks aged). Then, the babies were fasted overnight before sacrificing. After that, the babies were weighted, blood was collected and rats were sacrificing. Organs were removed and weighted.

Blood samples were collected from eye plexuses of each rat. It cold in refrigerator for $15 \mathrm{~min}$. The serum was separated by centrifuged at $3000 \mathrm{rpm}$ for $15 \mathrm{~min}$. Serum was carefully transferred into dry clean Eppendorf tubes and kept frozen at $-18^{\circ} \mathrm{C}$ till analysis. Liver, kidney, heart and femur were removed by careful dissection and blotted free of adhering blood immediately after sacrificing the rats. The organs were washed in saline and dried using filter paper, then weighted and kept in formalin $(10 \% \mathrm{v} / \mathrm{v})$ according to Drury and Wallington [16]. Femur was clean and dried in an oven on $105^{\circ} \mathrm{C}$ overnight and kept till analysis.

\subsection{Methods}

Biochemical assays: Serum triglycerides (TG), total cholesterol (TC) and high density lipoprotein cholesterol (HDL) were determined according to Allain et al., [17], Fossati and Principle [18] and Burstein [19], respectively. Meanwhile, low and very low density lipoprotein cholesterol (LDL and VLDL) were calculated using the equation reported by Essam El-Din [20]. The risk factor (TC/HDL-C ratio) was calculated using the equation reported by Abbott et al., [21]. Serum urea and creatinine as kidney function were determined by the methods of Patton and Crouch [22] and Bohmer [23], respectively. Serum AST and ALT were assayed according to Reitman and Frankel [24]. Serum alkaline phosphatase (ALP) was determined according to Belfield and Golobkrg [25].

Bone analysis: Bone $\mathrm{Ca}$ and $\mathrm{P}$ were determined according to the methods outlined in AOAC [26]. Length and thickness of each femur were measured using a varnein caliper according to the method of Arjmand et al., [27].

Statistical analysis: Statistical analyses were carried out bySPSS19 program. Data were expressed as means \pm SEM and the Statistical analysis was performed using one-way analysis of variance followed by Duncan's tests as according to Snedecor and Cochran [28]. 
Table (1). The experimental diets for rats ( $\mathrm{g} / 100 \mathrm{~g})$.

\begin{tabular}{|c|c|c|c|c|c|}
\hline Groups & Basal diet without oil & Corn oil & Virgin olive oil & $\begin{array}{l}\text { Extra virgin } \\
\text { olive oil }\end{array}$ & $\begin{array}{l}\text { Thyme leaves } \\
\text { powder }\end{array}$ \\
\hline 1 & 90 & 10 & -- & -- & -- \\
\hline 2 & 90 & 5 & 5 & -- & -- \\
\hline 3 & 90 & -- & 10 & -- & -- \\
\hline 4 & 90 & 5 & -- & 5 & -- \\
\hline 5 & 90 & -- & -- & 10 & -- \\
\hline 6 & 89 & 10 & -- & -- & 1 \\
\hline 7 & 87.5 & 10 & -- & -- & 2.5 \\
\hline 8 & 89 & 5 & 5 & -- & 1 \\
\hline 9 & 87.5 & 5 & 5 & -- & 2.5 \\
\hline 10 & 89 & -- & 10 & -- & 1 \\
\hline 11 & 87.5 & -- & 10 & -- & 2.5 \\
\hline 12 & 89 & 5 & -- & 5 & 1 \\
\hline 13 & 87.5 & 5 & -- & 5 & 2.5 \\
\hline 14 & 89 & -- & -- & 10 & 1 \\
\hline 15 & 87.5 & -- & -- & 10 & 2.5 \\
\hline
\end{tabular}

\section{Results}

Effect of feeding on olive oil and thyme powder diets on number of babies and their weight

Table (2). Effect of feeding on olive oil and thyme powder diets on number of babies and their weighted.

\begin{tabular}{|c|c|c|c|c|c|c|c|}
\hline \multirow{2}{*}{ Groups } & \multirow{2}{*}{$\begin{array}{l}\text { Total NO. } \\
\text { of babies }\end{array}$} & \multicolumn{3}{|l|}{ Male } & \multicolumn{3}{|c|}{ Female } \\
\hline & & No. & $\%$ & Weight (g) & No. & $\%$ & Weight (g) \\
\hline 1- Control & $7^{\mathrm{e}}$ & $3^{\mathrm{c}}$ & 42.86 & $88.22^{\mathrm{b}}$ & $4^{\mathrm{c}}$ & 57.14 & $80.00^{\mathrm{bc}}$ \\
\hline 2- $50 \%$ Virgin Olive Oil (VOO) & $8^{\mathrm{d}}$ & $3^{\mathrm{c}}$ & 37.50 & $82.32^{\mathrm{b}}$ & $5^{\mathrm{c}}$ & 62.50 & $76.00^{\mathrm{d}}$ \\
\hline 3- 100\% Virgin Olive Oil (VOO) & $9^{c}$ & $3^{\mathrm{c}}$ & 33.33 & $59.00^{\mathrm{e}}$ & $6^{\mathrm{b}}$ & 66.67 & $53.00^{\mathrm{f}}$ \\
\hline 4- 50\% Extra Virgin Olive Oil (EVOO) & $8^{\mathrm{d}}$ & $3^{\mathrm{c}}$ & 37.50 & $89.00^{\mathrm{a}}$ & $5^{\mathrm{c}}$ & 62.50 & $90.00^{\mathrm{a}}$ \\
\hline 5- 100\% Extra Virgin Olive Oil (EVOO) & $9^{c}$ & $3^{\mathrm{c}}$ & 33.33 & $81.67^{\mathrm{bc}}$ & $6^{\mathrm{b}}$ & 66.67 & $67.33^{\mathrm{e}}$ \\
\hline 7- $2.5 \%$ Thyme & $10^{\mathrm{b}}$ & $4^{\mathrm{b}}$ & 40.00 & $81.68^{\mathrm{b}}$ & $6^{\mathrm{b}}$ & 60.00 & $64.33^{\mathrm{e}}$ \\
\hline $8-50 \%$ VOO+1\%Thyme & $10^{\mathrm{b}}$ & $4^{\mathrm{b}}$ & 40.00 & $73.32^{\mathrm{cd}}$ & $6^{\mathrm{b}}$ & 60.00 & $70.00^{\mathrm{de}}$ \\
\hline $9-50 \%$ VOO $+2.5 \%$ Thyme & $12^{\mathrm{a}}$ & $5^{\mathrm{a}}$ & 41.67 & $58.33^{\mathrm{e}}$ & $7^{\mathrm{a}}$ & 58.33 & $49.33^{\mathrm{f}}$ \\
\hline $10-100 \%$ VOO+1\%Thyme & $11^{\mathrm{ab}}$ & $4^{\mathrm{b}}$ & 36.36 & $73.31^{\mathrm{cd}}$ & $7^{\mathrm{a}}$ & 63.64 & $55.00^{\mathrm{f}}$ \\
\hline $11-100 \%$ VOO $+2.5 \%$ Thyme & $12^{\mathrm{a}}$ & $5^{\mathrm{a}}$ & 41.67 & $58.34^{\mathrm{e}}$ & $7^{\mathrm{a}}$ & 58.33 & $54.33^{\mathrm{f}}$ \\
\hline $12-50 \%($ EVOO $)+1 \%$ Thyme & $9^{c}$ & $3^{\mathrm{c}}$ & 33.33 & $81.67^{\mathrm{bc}}$ & $6^{\mathrm{b}}$ & 66.67 & $78.33^{\mathrm{bc}}$ \\
\hline $14-100 \%($ EVOO $)+1 \%$ Thyme & $10^{\mathrm{b}}$ & $4^{\mathrm{b}}$ & 40.00 & $90.00^{\mathrm{a}}$ & $6^{\mathrm{b}}$ & 60.00 & $85.00^{\mathrm{b}}$ \\
\hline $15-100 \%($ EVOO $)+2.5 \%$ Thyme & $12^{\mathrm{a}}$ & $5^{\mathrm{a}}$ & 41.67 & $65.68^{\mathrm{d}}$ & $7^{\mathrm{a}}$ & 58.33 & $53.33^{\mathrm{f}}$ \\
\hline
\end{tabular}

* Value in a column followed by the same letter are not significantly different at $\mathrm{p} \leq 0.05$.

The results in table (2) showed that, the effect of feeding on olive oil and thyme powder on number of outcome of pregnancy and their weight. Generally, all groups fed on olive oil and thyme powder (individually and combined with all percentages) had a high number of babies compared to control group. The combination between olive oil and thyme powder had higher number of babies than either alone. Also, the groups fed on percentages $(100 \%$ olive oil and $2.5 \%$ thyme) had a high number of babies (either alone or both). Moreover, the groups fed on VOO and thyme powder had a high number of babies compared to groups fed on EVOO and thyme powder.

Generally, there is a negative relationship between number of babies and their weights. The male body weight was higher than female weight. The group fed on $50 \%$ of EVOO only had the highest value of body weight followed by the control group (each male and female). While, the groups fed on VOO and thyme powder had low body weight compared to groups fed on EVOO and thyme powder.

\subsection{Effect of Feeding on Olive Oil and Thyme Powder Diets on Weight of Some Organs for Male and Female Babies}

The results in table (3) showed that, the effect of feeding on olive oil and thyme powder on organs weight for male and female babies. Generally, the group fed on 50\% EVOO alone had the highest level of organs weight. The rats in groups fed 
on $100 \%$ olive oil with or without thyme powder were lower than groups fed on $50 \%$ olive oil for organs weight. The rats in groups fed on EVOO and thyme powder were lower than groups fed on VOO and thyme powder for liver weight.
While, kidney, heart and spleen weight in groups fed on EVOO and thyme powder were higher than group fed on VOO and thyme powder (both male and female).

Table (3). Effect of feeding on olive oil and thyme powder diets on weight of some organs for male and female babies.

\begin{tabular}{|c|c|c|c|c|c|c|c|c|}
\hline \multirow{2}{*}{ Groups } & \multicolumn{4}{|l|}{ Male } & \multicolumn{4}{|c|}{ Female } \\
\hline & Liver & Kidney & Heart & Spleen & Liver & Kidney & Heart & Spleen \\
\hline 1- control & $1.34^{\mathrm{g}}$ & $0.33^{\mathrm{d}}$ & $0.23^{\mathrm{c}}$ & $0.24^{\mathrm{b}}$ & $2.44^{\mathrm{c}}$ & $0.63^{\mathrm{a}}$ & $0.22^{\mathrm{b}}$ & $0.08^{\mathrm{d}}$ \\
\hline 2- 50\% Virgin Olive Oil (VOO) & $1.35^{\mathrm{g}}$ & $0.31^{\mathrm{d}}$ & $0.23^{\mathrm{c}}$ & $0.07^{\mathrm{c}}$ & $1.35^{\mathrm{h}}$ & $0.10^{\mathrm{e}}$ & $0.33^{\mathrm{a}}$ & $0.08^{\mathrm{d}}$ \\
\hline 3- 100\% Virgin Olive Oil (VOO) & $1.14^{\mathrm{g}}$ & $0.09^{\mathrm{e}}$ & $0.33^{\mathrm{b}}$ & $0.08^{\mathrm{c}}$ & $1.14^{\mathrm{i}}$ & $0.31^{\mathrm{d}}$ & $0.23^{b}$ & $0.29^{\mathrm{b}}$ \\
\hline 4- $50 \%$ Extra Virgin Olive Oil (EVOO) & $3.00^{\mathrm{a}}$ & $0.60^{\mathrm{a}}$ & $0.42^{\mathrm{a}}$ & $0.22^{\mathrm{b}}$ & $3.27^{\mathrm{a}}$ & $0.55^{\mathrm{b}}$ & $0.33^{\mathrm{a}}$ & $0.22^{\mathrm{c}}$ \\
\hline 5- $100 \%$ Extra Virgin Olive Oil (EVOO) & $1.84^{\mathrm{f}}$ & $0.50^{\mathrm{b}}$ & $0.25^{\mathrm{c}}$ & $0.21^{\mathrm{b}}$ & $1.72^{\mathrm{g}}$ & $0.51^{\mathrm{b}}$ & $0.22^{\mathrm{b}}$ & $0.35^{\mathrm{a}}$ \\
\hline 7- $2.5 \%$ Thyme & $2.31^{\mathrm{cd}}$ & $0.42^{\mathrm{c}}$ & $0.33^{\mathrm{b}}$ & $0.25^{\mathrm{b}}$ & $2.33^{\mathrm{c}}$ & $0.53^{\mathrm{b}}$ & $0.24^{\mathrm{b}}$ & $0.24^{\mathrm{c}}$ \\
\hline 8- $50 \%$ VOO+1\%Thyme & $2.35^{\mathrm{cd}}$ & $0.33^{\mathrm{d}}$ & $0.23^{\mathrm{c}}$ & $0.23^{\mathrm{b}}$ & $2.33^{\mathrm{c}}$ & $0.34^{\mathrm{d}}$ & $0.23^{\mathrm{b}}$ & $0.35^{\mathrm{a}}$ \\
\hline 9- $50 \%$ VOO+2.5\% Thyme & $1.93^{\mathrm{ef}}$ & $0.32^{\mathrm{d}}$ & $0.21^{\mathrm{c}}$ & $0.25^{\mathrm{b}}$ & $1.85^{\mathrm{ef}}$ & $0.31^{\mathrm{d}}$ & $0.24^{\mathrm{b}}$ & $0.25^{\mathrm{bc}}$ \\
\hline $10-100 \%$ VOO+1\%Thyme & $2.50^{\mathrm{bc}}$ & $0.33^{d}$ & $0.42^{\mathrm{b}}$ & $0.30^{\mathrm{a}}$ & $2.72^{\mathrm{b}}$ & $0.40^{\mathrm{c}}$ & $0.33^{\mathrm{a}}$ & $0.34^{\mathrm{a}}$ \\
\hline $11-100 \%$ VOO+2.5\% Thyme & $2.16^{\mathrm{de}}$ & $0.43^{\mathrm{c}}$ & $0.23^{\mathrm{c}}$ & $0.15^{\mathrm{c}}$ & $1.82^{\mathrm{fg}}$ & $0.31^{\mathrm{d}}$ & $0.23^{\mathrm{b}}$ & $0.25^{\mathrm{bc}}$ \\
\hline $12-50 \%($ EVOO $)+1 \%$ Thyme & $2.18^{\mathrm{de}}$ & $0.60^{\mathrm{a}}$ & $0.33^{\mathrm{b}}$ & $0.10^{\mathrm{c}}$ & $2.10^{\mathrm{d}}$ & $0.52^{\mathrm{b}}$ & $0.35^{\mathrm{a}}$ & $0.33^{\mathrm{a}}$ \\
\hline $13-50 \%($ EVOO $)+2.5 \%$ Thyme & $1.91^{\mathrm{ef}}$ & $0.52^{\mathrm{b}}$ & $0.32^{\mathrm{b}}$ & $0.22^{\mathrm{b}}$ & $1.96^{\mathrm{e}}$ & $0.63^{\mathrm{a}}$ & $0.23^{\mathrm{b}}$ & $0.22^{\mathrm{c}}$ \\
\hline $15-100 \%($ EVOO $)+2.5 \%$ Thyme & $1.82^{\mathrm{f}}$ & $0.42^{\mathrm{c}}$ & $0.23^{\mathrm{c}}$ & $0.09^{\mathrm{c}}$ & $1.35^{\mathrm{h}}$ & $0.40^{\mathrm{c}}$ & $0.23^{\mathrm{b}}$ & $0.24^{\mathrm{c}}$ \\
\hline
\end{tabular}

* Value in a column followed by the same letter are not significantly different at $\mathrm{p} \leq 0.05$.

\subsection{Effect of Feeding on Olive Oils and Thyme Powder Diets on Lipid Profile for Male and Female Babies}

Table (4). Effect of feeding on olive oils and thyme powder diets on lipid profile for male and female babies.

\begin{tabular}{|c|c|c|c|c|c|c|c|c|c|c|c|c|}
\hline \multirow[b]{2}{*}{ Groups } & \multicolumn{6}{|l|}{ Male } & \multicolumn{6}{|l|}{ Female } \\
\hline & T. C. & T.G. & HDL-C & $\begin{array}{l}\text { LDL- } \\
\text { C }\end{array}$ & $\begin{array}{l}\text { VLDL- } \\
\text { C }\end{array}$ & $\begin{array}{l}\text { Risk } \\
\text { factor }\end{array}$ & T. C. & T.G. & HDL-C & $\begin{array}{l}\text { LDL- } \\
\text { C }\end{array}$ & $\begin{array}{l}\text { VLDL- } \\
\text { C }\end{array}$ & $\begin{array}{l}\text { Risk } \\
\text { factor }\end{array}$ \\
\hline 1- control & $92.33^{\mathrm{a}}$ & $82.33^{\mathrm{a}}$ & $36.67^{\mathrm{g}}$ & $39.19^{\text {de }}$ & $16.46^{\mathrm{a}}$ & $2.52^{\mathrm{g}}$ & $91.20^{\mathrm{bc}}$ & $89.00^{\mathrm{a}}$ & $50.67^{\text {bcd }}$ & $22.73^{\text {bc }}$ & $17.80^{\mathrm{a}}$ & $1.80^{1}$ \\
\hline $\begin{array}{l}\text { 2- } 50 \% \text { Virgin Olive } \\
\text { Oil (VOO) }\end{array}$ & $122.67^{f}$ & $93.32^{\mathrm{a}}$ & $48.00^{\text {bcd }}$ & $56.01^{\mathrm{gh}}$ & $18.67^{\mathrm{b}}$ & $2.56^{\mathrm{g}}$ & $95.80^{\mathrm{b}}$ & $86.00^{\mathrm{a}}$ & $39.33^{\mathrm{hi}}$ & $29.20^{\mathrm{de}}$ & $17.27^{\mathrm{a}}$ & $2.44^{\mathrm{d}}$ \\
\hline $\begin{array}{l}\text { 3- } 100 \% \text { Virgin Olive } \\
\text { Oil (VOO) }\end{array}$ & $104.67^{b}$ & $92.67^{\mathrm{a}}$ & $41.67^{\mathrm{fg}}$ & $44.47^{\mathrm{ef}}$ & $18.53^{b}$ & $2.51^{\mathrm{g}}$ & $98.67^{\text {cde }}$ & $150.33^{\mathrm{g}}$ & $43.00^{\text {fgh }}$ & $25.60^{\mathrm{cd}}$ & $30.07^{\mathrm{g}}$ & $2.29^{f}$ \\
\hline $\begin{array}{l}\text { 4- 50\% Extra Virgin } \\
\text { Olive Oil (EVOO) }\end{array}$ & $108.66^{\mathrm{bc}}$ & $102.00^{\mathrm{cd}}$ & $39.33^{\mathrm{fg}}$ & $48.93^{\mathrm{fg}}$ & $20.40^{\mathrm{cd}}$ & $2.76^{\mathrm{c}}$ & $95.37^{\mathrm{cd}}$ & $130.00^{\text {ef }}$ & $46.00^{\mathrm{def}}$ & $23.37^{\mathrm{c}}$ & $26.00^{\mathrm{ef}}$ & $2.07^{\mathrm{j}}$ \\
\hline $\begin{array}{l}5-100 \% \text { Extra Virgin } \\
\text { Olive Oil (EVOO) }\end{array}$ & $106.00^{\mathrm{b}}$ & $121.67^{\mathrm{e}}$ & $51.67^{\mathrm{ab}}$ & $30.00^{\mathrm{bc}}$ & $24.33^{\mathrm{e}}$ & $2.05^{\mathrm{h}}$ & $113.67^{\text {hi }}$ & $102.33^{\mathrm{abcd}}$ & $49.07^{\text {bcde }}$ & $44.13^{\mathrm{h}}$ & $20.47^{\mathrm{abcd}}$ & $2.32^{f}$ \\
\hline $6-1 \%$ Thyme & $133.00^{\mathrm{h}}$ & $131.00^{\mathrm{fg}}$ & $50.00^{\mathrm{bc}}$ & $56.80^{\mathrm{gh}}$ & $26.20^{\mathrm{fg}}$ & $2.66^{\mathrm{ef}}$ & $104.00^{\mathrm{efg}}$ & $139.67^{\mathrm{fg}}$ & $58.67^{\mathrm{a}}$ & $17.40^{\mathrm{b}}$ & $27.93^{\mathrm{fg}}$ & $1.77^{\mathrm{m}}$ \\
\hline 7- 2.5\% Thyme & $93.67^{\mathrm{a}}$ & $109.66^{\mathrm{d}}$ & $44.67^{\text {cdef }}$ & $27.07^{\mathrm{bc}}$ & $21.93^{\mathrm{d}}$ & $2.10^{\mathrm{h}}$ & $111.50^{\text {ghi }}$ & $103.00^{\mathrm{abcd}}$ & $51.00^{\mathrm{bc}}$ & $39.90^{\text {gh }}$ & $20.60^{\text {abcd }}$ & $2.19^{\mathrm{h}}$ \\
\hline $\begin{array}{l}8-50 \% \\
\text { VOO+1\%Thyme }\end{array}$ & $117.33^{\text {de }}$ & $130.68^{\mathrm{fg}}$ & $40.33^{\mathrm{fg}}$ & $50.87^{\mathrm{fg}}$ & $26.12^{\mathrm{fg}}$ & $2.91^{\mathrm{b}}$ & $118.83^{\mathrm{a}}$ & $100.00^{\mathrm{abc}}$ & $40.77^{\text {ghi }}$ & $58.06^{\mathrm{a}}$ & $20.00^{\mathrm{abc}}$ & $2.91^{\mathrm{a}}$ \\
\hline $\begin{array}{l}9-50 \% \\
\text { VOO+2.5\% Thyme }\end{array}$ & $113.33^{\mathrm{cd}}$ & $98.33^{b c}$ & $41.67^{\text {efg }}$ & $51.99^{\mathrm{fg}}$ & $19.67^{\mathrm{bc}}$ & $2.72^{\mathrm{cd}}$ & $107.33^{\text {fgh }}$ & $97.67^{\mathrm{ab}}$ & $42.40^{\mathrm{fgh}}$ & $45.40^{\mathrm{h}}$ & $19.53^{\mathrm{ab}}$ & $2.53^{\mathrm{c}}$ \\
\hline $\begin{array}{l}10-100 \% \\
\text { VOO }+1 \% \text { Thyme }\end{array}$ & $95.00^{\mathrm{a}}$ & $125.66^{\mathrm{ef}}$ & $56.00^{\mathrm{a}}$ & $13.88^{\mathrm{a}}$ & $25.13^{\text {ef }}$ & $1.70^{\mathrm{j}}$ & $96.67^{\text {cde }}$ & $121.00^{\text {def }}$ & $52.00^{\mathrm{b}}$ & $20.47^{\mathrm{bc}}$ & $24.20^{\mathrm{def}}$ & $1.86^{\mathrm{k}}$ \\
\hline $\begin{array}{l}11-100 \% \\
\text { VOO+2.5\% Thyme }\end{array}$ & $93.00^{\mathrm{a}}$ & $99.67^{\mathrm{bc}}$ & $49.33^{b}$ & $23.73^{\mathrm{b}}$ & $19.94^{\mathrm{bc}}$ & $1.89^{\mathrm{i}}$ & $109.00^{\mathrm{fgh}}$ & $111.33^{\mathrm{bcd}}$ & $45.40^{\text {efg }}$ & $41.33^{\mathrm{h}}$ & $22.27^{\text {bcde }}$ & $2.40^{\mathrm{e}}$ \\
\hline $\begin{array}{l}12-50 \%(\text { EVOO })+ \\
1 \% \text { Thyme }\end{array}$ & $127.67^{\mathrm{g}}$ & $108.33^{\mathrm{d}}$ & $43.00^{\mathrm{def}}$ & $63.00^{\mathrm{h}}$ & $21.67^{\mathrm{d}}$ & $2.97^{\mathrm{a}}$ & $110.40^{\mathrm{fg}}$ & $118.03^{\text {cde }}$ & $51.50^{\mathrm{bc}}$ & $35.29^{\mathrm{gh}}$ & $23.61^{\text {cde }}$ & $2.14^{\mathrm{i}}$ \\
\hline $\begin{array}{l}13-50 \%(\text { EVOO })+ \\
2.5 \% \text { Thyme }\end{array}$ & $122.00^{\mathrm{ef}}$ & $126.67^{\mathrm{ef}}$ & $46.33^{\text {bcde }}$ & $50.34^{\mathrm{fg}}$ & $25.33^{\mathrm{ef}}$ & $2.63^{f}$ & $98.17^{\text {cde }}$ & $129.33^{\mathrm{ef}}$ & $36.83^{\mathrm{i}}$ & $35.47^{\mathrm{fg}}$ & $25.87^{\mathrm{ef}}$ & $2.67^{b}$ \\
\hline $\begin{array}{l}14-100 \%(\text { EVOO })+ \\
1 \% \text { Thyme }\end{array}$ & $116.00^{d}$ & $138.00^{\mathrm{g}}$ & $56.00^{\mathrm{a}}$ & $32.40^{\mathrm{cd}}$ & $27.60^{\mathrm{g}}$ & $2.07^{\mathrm{h}}$ & $101.67^{\text {def }}$ & $120.33^{\mathrm{def}}$ & $45.33^{\text {efg }}$ & $32.27^{\mathrm{ef}}$ & $24.07^{\text {def }}$ & $2.24^{\mathrm{g}}$ \\
\hline $\begin{array}{l}15-100 \%(\text { EVOO })+ \\
2.5 \% \text { Thyme }\end{array}$ & $113.67^{\mathrm{cd}}$ & $102.67^{\mathrm{cd}}$ & $42.33^{\operatorname{defg}}$ & $50.81^{\mathrm{fg}}$ & $20.53^{\mathrm{cd}}$ & $2.69^{\mathrm{de}}$ & $118.33^{\mathrm{i}}$ & $104.67^{\mathrm{abcd}}$ & $46.57^{\text {cdef }}$ & $50.83^{\mathrm{i}}$ & $20.93^{\mathrm{abcd}}$ & $2.54^{\mathrm{c}}$ \\
\hline
\end{tabular}

* Value in a column followed by the same letter are not significantly different at $\mathrm{p} \leq 0.05$.

The results in table (4) showed that, the effect of feeding on olive oils and thyme powder diets on lipid profile. The data resulted in the control group was the lowest level of lipid profile compared to other groups which fed on olive oils 
and thyme diets. The feeding on VOO (100\%) caused decrease in lipid profile compared to VOO $(50 \%)$ for male babies. And, the feeding on EVOO (100\%) caused decrease in TC, LDL-C and risk factor and increase in TG and VLDL$\mathrm{C}$ for male babies. Feeding on thyme powder $(2.5 \%)$ caused decrease in lipid profile compared to (1\%) thyme powder. Meanwhile, the groups fed on EVOO and thyme powder were higher than level of TC, TG, LDL-C and risk factor compared to groups fed on $\mathrm{VOO}$ and thyme powder.

Concerning female babies, the results noticed that a high differences in lipid profile between groups. Generally, the groups fed on EVOO and thyme powder were higher than groups fed on VOO and thyme powder for lipid profile. The rats fed on olive oils (100\%) were increase of TC compared to rats fed on $50 \%$. The groups fed on VOO $(100 \%)$ and thyme powder ( $1 \%$ and $2.5 \%)$ decreased in TC, LDL-C and risk factor and increased in TG and VLDL-C. The group fed on thyme powder (2.5\%) and VOO (50\% and $100 \%)$ resulted in decrease of TG and VLDL-C compared to group fed on thyme powder (1\%) and VOO (50\% and $100 \%)$. Meanwhile, the groups fed on EVOO (100\%) and thyme powder $(1 \%$ and
$2.5 \%)$ increased in TC. The groups fed on EVOO (100\%) and thyme powder $(2.5 \%)$ had decrease in TG, VLDL-C and risk factor compared to group fed on EVOO (50\%) and thyme powder $(2.5 \%)$. The results may be due to recommendation and hormones cycle in female especially during growth.

\subsection{Effect of Feeding on Olive Oils and Thyme Powder Diets on Liver and Kidney Functions for Male and Female Babies}

The results in table (5) showed that, the effect of feeding on olive oils and thyme powder on liver and kidney functions for male female babies. Generally, the groups fed on olive oils $(100 \%)$ and thyme powder $(2.5 \%)$ resulted in decrease in kidney functions for male babies. The groups fed on VOO and thyme powder were higher in kidney functions for male babies than groups fed on VOO and thyme powder. The rats in control group had the lowest level of serum creatinine compared to groups fed on olive oil.

Table (5). Effect of feeding on olive oils and thyme powder diets on kidney and liver functions for male and female babies.

\begin{tabular}{|c|c|c|c|c|c|c|c|c|c|c|}
\hline \multirow{3}{*}{ Groups } & \multicolumn{5}{|l|}{ Male } & \multicolumn{5}{|l|}{ Female } \\
\hline & \multicolumn{2}{|c|}{ Kidney functions } & \multicolumn{2}{|c|}{ Liver functions } & \multirow[b]{2}{*}{ ALK } & \multicolumn{2}{|c|}{ Kidney functions } & \multicolumn{2}{|c|}{ Liver functions } & \multirow[b]{2}{*}{ ALK } \\
\hline & Urea & Creat. & AST & ALT & & Urea & Creat. & AST & ALT & \\
\hline 1 control & $20.67^{\mathrm{de}}$ & $0.67^{\mathrm{ef}}$ & $19.33^{\mathrm{bc}}$ & $18.33^{\mathrm{ab}}$ & $109.67^{\mathrm{d}}$ & $28.80^{\mathrm{ab}}$ & $0.93^{\mathrm{ab}}$ & $15.33^{\mathrm{fg}}$ & $14.27^{\mathrm{g}}$ & $150.33^{\mathrm{abc}}$ \\
\hline $250 \%$ Virgin Olive Oil (VOO) & $33.33^{\mathrm{a}}$ & $1.06^{\mathrm{a}}$ & $14.33^{\mathrm{fg}}$ & $12.00^{\mathrm{e}}$ & $138.33^{\mathrm{a}}$ & $26.73^{\text {bcd }}$ & $0.80^{\mathrm{bc}}$ & $19.80^{\mathrm{bc}}$ & $18.60^{\text {cd }}$ & $102.33^{\mathrm{fg}}$ \\
\hline $\begin{array}{l}3 \text { 100\% Virgin Olive Oil } \\
\text { (VOO) }\end{array}$ & $29.33^{\mathrm{b}}$ & $0.89^{\mathrm{b}}$ & $18.00^{\text {cde }}$ & $19.00^{\mathrm{ab}}$ & $113.00^{\mathrm{cd}}$ & $20.00^{\text {efgh }}$ & $0.71^{\mathrm{cd}}$ & $16.40^{\mathrm{ef}}$ & $17.43^{\mathrm{de}}$ & $128.67^{\mathrm{e}}$ \\
\hline $\begin{array}{l}450 \% \text { Extra Virgin Olive Oil } \\
\text { (EVOO) }\end{array}$ & $32.67^{\mathrm{a}}$ & $0.99^{\mathrm{a}}$ & $20.00^{\mathrm{abc}}$ & $19.00^{\mathrm{ab}}$ & $97.00^{\mathrm{e}}$ & $22.67^{\text {defg }}$ & $0.76^{\mathrm{cd}}$ & $16.07^{\text {ef }}$ & $16.33^{\text {ef }}$ & $136.00^{\mathrm{de}}$ \\
\hline $\begin{array}{l}5100 \% \text { Extra Virgin Olive Oil } \\
\text { (EVOO) }\end{array}$ & $23.00^{\mathrm{cd}}$ & $0.85^{\mathrm{bc}}$ & $18.00^{\text {cde }}$ & $18.33^{\mathrm{ab}}$ & $123.00^{\mathrm{bc}}$ & $17.13^{\mathrm{h}}$ & $0.53^{\mathrm{e}}$ & $19.87^{\mathrm{bc}}$ & $19.20^{\mathrm{bc}}$ & $152.73^{\mathrm{ab}}$ \\
\hline $61 \%$ Thyme & $18.00^{\mathrm{e}}$ & $0.64^{\mathrm{f}}$ & $15.33^{\mathrm{efg}}$ & $13.00^{\mathrm{e}}$ & $114.33^{\text {cd }}$ & $32.00^{\mathrm{a}}$ & $1.07^{\mathrm{a}}$ & $17.23^{\mathrm{de}}$ & $15.40^{\mathrm{fg}}$ & $144.67^{\text {bcd }}$ \\
\hline $72.5 \%$ Thyme & $17.67^{\mathrm{e}}$ & $0.63^{\mathrm{f}}$ & $21.67^{\mathrm{ab}}$ & $20.33^{\mathrm{a}}$ & $87.33^{\mathrm{e}}$ & $29.67^{\mathrm{ab}}$ & $1.00^{\mathrm{a}}$ & $20.77^{\mathrm{ab}}$ & $18.57^{\mathrm{cd}}$ & $138.27^{\mathrm{cde}}$ \\
\hline $850 \%$ VOO+1\%Thyme & $25.33^{\mathrm{c}}$ & $0.80^{\text {cd }}$ & $18.67^{\mathrm{cd}}$ & $16.67^{\mathrm{bcd}}$ & $110.00^{\mathrm{d}}$ & $22.03^{\mathrm{efg}}$ & $0.71^{\mathrm{cd}}$ & $13.00^{\mathrm{h}}$ & $12.60^{\mathrm{h}}$ & $160.07^{\mathrm{a}}$ \\
\hline $950 \%$ VOO+2.5\% Thyme & $19.00^{\mathrm{e}}$ & $0.75^{\mathrm{de}}$ & $22.68^{\mathrm{a}}$ & $11.67^{\mathrm{e}}$ & $98.67^{\mathrm{e}}$ & $23.10^{\text {def }}$ & $0.80^{\mathrm{bc}}$ & $18.23^{\mathrm{cd}}$ & $16.50^{\text {ef }}$ & $159.80^{\mathrm{a}}$ \\
\hline 10 100\% VOO+1\%Thyme & $24.00^{\mathrm{c}}$ & $0.79^{\mathrm{cd}}$ & $17.67^{\text {cde }}$ & $14.67^{\text {cde }}$ & $94.33^{\mathrm{e}}$ & $20.87^{\text {efgh }}$ & $0.81^{\mathrm{bc}}$ & $14.33^{\mathrm{gh}}$ & $20.20^{\mathrm{ab}}$ & $149.33^{\mathrm{abcd}}$ \\
\hline $11100 \%$ VOO+2.5\% Thyme & $19.33^{\mathrm{e}}$ & $0.72^{\text {def }}$ & $17.00^{\text {cdef }}$ & $14.67^{\text {cde }}$ & $116.33^{\mathrm{bcd}}$ & $21.13^{\text {efgh }}$ & $0.70^{\text {cd }}$ & $19.87^{\mathrm{bc}}$ & $19.87^{\mathrm{abc}}$ & $140.07^{\text {bcdc }}$ \\
\hline $1250 \%($ EVOO $)+1 \%$ Thyme & $33.00^{\mathrm{a}}$ & $1.00^{\mathrm{a}}$ & $18.00^{\text {cde }}$ & $17.33^{\mathrm{abc}}$ & $121.67^{\mathrm{bcd}}$ & $18.80^{\mathrm{fgh}}$ & $0.61^{\text {de }}$ & $16.47^{\text {ef }}$ & $15.63^{\mathrm{fg}}$ & $99.00^{\mathrm{g}}$ \\
\hline $1350 \%$ (EVOO) $+2.5 \%$ Thyme & $29.33^{b}$ & $0.99^{\mathrm{a}}$ & $13.00^{\mathrm{g}}$ & $20.33^{\mathrm{a}}$ & $112.67^{\mathrm{cd}}$ & $26.63^{\mathrm{bcd}}$ & $1.03^{\mathrm{a}}$ & $20.17^{\mathrm{b}}$ & $21.13^{\mathrm{a}}$ & $114.50^{\mathrm{f}}$ \\
\hline $14100 \%$ (EVOO) $+1 \%$ Thyme & $25.00^{\mathrm{c}}$ & $0.84^{\mathrm{bc}}$ & $15.67^{\text {defg }}$ & $13.33^{\mathrm{e}}$ & $117.67^{\mathrm{bcd}}$ & $18.33^{\text {gh }}$ & $0.61^{\mathrm{de}}$ & $19.27^{\mathrm{bc}}$ & $12.63^{\mathrm{h}}$ & $107.67^{\mathrm{fg}}$ \\
\hline $\begin{array}{l}15100 \%(\text { EVOO })+ \\
2.5 \% \text { Thyme }\end{array}$ & $20.33^{\mathrm{de}}$ & $0.80^{\text {cd }}$ & $16.00^{\operatorname{defg}}$ & $13.67^{\mathrm{de}}$ & $127.33^{\mathrm{b}}$ & $24.10^{\text {cde }}$ & $0.71^{\mathrm{cd}}$ & $22.03^{\mathrm{a}}$ & $17.50^{\mathrm{de}}$ & $130.80^{\mathrm{e}}$ \\
\hline
\end{tabular}

* Value in a column followed by the same letter are not significantly different at $\mathrm{p} \leq 0.05$.

Concerning liver functions, the results showed that, the group fed on VOO (100\%) caused in an increment of AST and ALT and decrease of ALP levels compared to VOO $(50 \%)$. While, the group fed on EVOO $(100 \%)$ was decrease in AST and ALT and increase in ALP levels compared to group fed on EVOO (50\%). Additional of thyme powder $(2.5 \%)$ was higher than (1\%) for AST and ALT, but ALP was a low. The data in same table (5) showed that, the groups fed on EVOO and thyme powder were higher than groups fed on VOO and thyme powder for ALT and ALP, while AST was a low.

Concerning the female babies, the data in table (5) resulted in there were high differences between male and female. Generally, the rats in control group had higher serum urea and creatinine contents than groups fed on olive oils, and lower than groups fed on thyme. The feeding on olive oils $(100 \%)$ and thyme powder $(2.5 \%)$ caused in decrement in kidney functions compared to olive oil $(50 \%)$ and thyme powder. The groups fed on thyme powder (1\%) and olive oils were lower than groups fed on thyme powder $(2.5 \%)$ and olive oils for serum urea content. Meanwhile, the groups fed on thyme powder $(1 \%)$ and $\mathrm{VOO}$ were higher than groups fed on thyme powder (1\%) and EVOO, but the groups fed on thyme powder $(2.5 \%)$ and EVOO were higher than groups 
fed on thyme powder $(2.5 \%)$ and VOO for serum urea content. Serum creatinine was a low level in groups fed on EVOO and thyme powder when compared to groups fed on VOO and thyme powder.

The results in the same table (5) showed that, the group fed on $100 \%$ VOO caused in decrease in AST and ALT when compared to group fed on $50 \%$ VOO. While, the group fed on EVOO (100\%) was increase in AST and ALT compared to group fed on $50 \%$ EVOO. On other hand, both VOO and EVOO (100\%) caused in an increase of ALP levels. The rats fed on thyme powder $(2.5 \%)$ were increased in AST, ALT and ALP compared to group fed on thyme powder (1\%). The groups fed on VOO $(100 \%)$ and thyme powder were higher than groups fed on VOO $(50 \%)$ and thyme powder for AST and ALT. While, the groups fed on thyme powder $(2.5 \%)$ with 50 and $100 \%$ of EVOO had high values of AST and ALT compared to groups fed on thyme powder (1\%) with EVOO. The groups fed on EVOO and thyme powder were lower ALP content than groups fed on VOO and thyme powder.

\subsection{Effect of Feeding on Olive Oils and Thyme Powder Diets on Measurements' Bone for Male and Female Babies}

Table (6). Effect of feeding on olive oils and thyme powder diets on Measurements' bone for male and female babies.

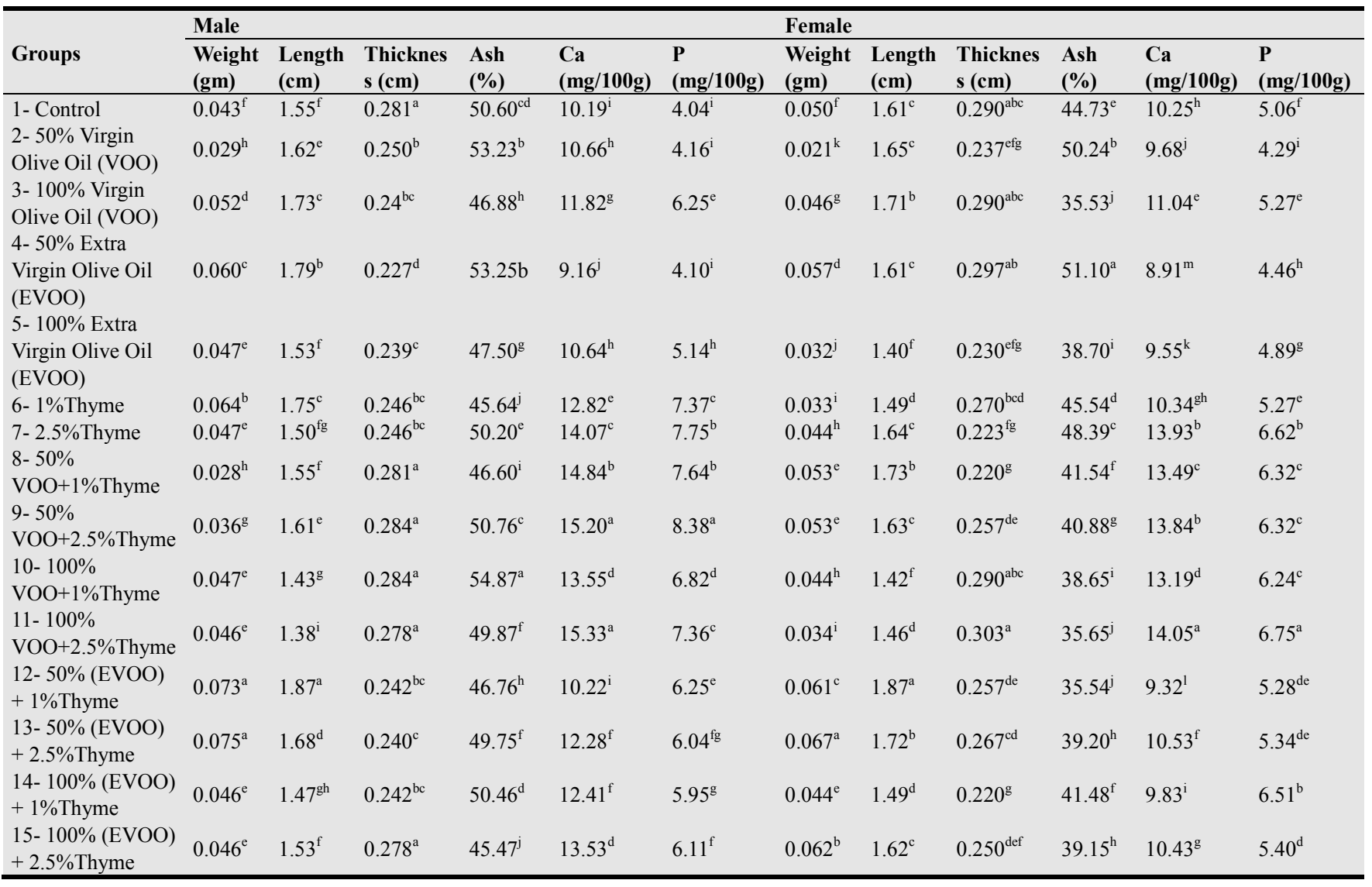

* Value in a column followed by the same letter are not significantly different at $\mathrm{p} \leq 0.05$.

The results in table (6) showed that, the effect of feeding on olive oils and thyme powder on measurements' bone for male and female babies. Generally, using VOO (100\%) in feeding caused to increase in femur weight compared to $50 \%$ VOO, while using EVOO (100\%) in feeding caused to decrease in femur weight compared to $50 \%$ EVOO for male and female babies. The groups fed on VOO (100\%) and thyme powder were higher femur weight than groups fed on VOO (50\%) and thyme powder, while groups fed on EVOO $(100 \%)$ and thyme powder were lower femur weight than groups fed on EVOO (50\%) and thyme powder for male and female babies. The results for female showed that, the groups fed on VOO (100\%) and thyme powder were lower femur weight than groups fed on VOO (50\%), while almost a similar resulted in EVOO (both 50 and 100\%).

Feeding on VOO (100\%) caused to increase in bone length, while feeding on EVOO (100\%) caused to decrease in femur length for male and female babies. The female results in the groups fed on VOO and EVOO and thyme powder were higher than groups fed on $100 \%$ both VOO and EVOO and thyme powder for femur length.

Concerning bone thickness, the results in table (6) indicated that, feeding on VOO $(100 \%)$ caused to decrease in bone thickness and EVOO (100\%) caused to increase in femur thickness for male babies. Meanwhile, feeding on VOO $(100 \%)$ caused to increase in femur thickness and EVOO (100\%) caused to decrease in femur thickness for male and female babies. The results showed that, the groups 
fed on VOO and thyme powder were higher than groups fed on EVOO and thyme powder for femur thickness male and female babies.

Moreover, the results indicated that feeding on both VOO and EVOO (100\%) caused to decrease in total bone mineral content TBMC for femur (ash, \%) in male and female babies. The groups fed on VOO (50\%) and thyme powder were higher than groups fed on EVOO (50\%) and thyme powder for TBMC. While, groups fed on EVOO (100\%) and thyme powder were lower than groups fed on VOO (100\%) and thyme powder for TBMC in both male and female babies.

The data in the same table (6) showed that, effect of feeding on olive oils and thyme powder on bone $\mathrm{Ca}$ and $\mathrm{P}$ contents. The results indicated that the rats fed on VOO were higher than rats fed on EVOO (individually and combined with all percentages) for femur $\mathrm{Ca}$ and $\mathrm{P}$ contents in both male and female babies.

\section{Discussion}

Nutrition in pregnancy, during lactation, childhood, and later stages has a fundamental influence on overall development. There is a growing research interest on the role of key dietary nutrients in fetal health [29]. Increasing of body weight and number of outcomes of pregnancy in this study are lines with [30] who found that, the groups fed on $(50 \%)$ of olive oil were higher than groups fed on $(100 \%)$ of olive oil and groups fed on VOO and thyme powder were lower than groups fed on EVOO and thyme powder for body weight gain. The rats fed on thyme $(2.5 \%)$ were lower than rats fed on thyme (1\%) for body weight gain. Also, it is worth mentioning that the presence of olive oil with/without thyme resulted in an increase in the number of outcomes of pregnancy compared to control.

Improvements in lipid profile in mice fed on the diet containing olive oil may be explains on the basis that olive oil is a rich source of monounsaturated fatty acids (MUSFA) that improves blood lipid profile. Olive oil is excellent source of oleic acid. Previous studies demonstrated that olive oils containing a large fraction of MUSFAs and a substantial amount of PUSFAs promote a better triacylglycerol clearance from the blood [31]. In additionally, a diet with olive oil is a good source of monounsaturated fatty reduced serum TG, LDL-c concentrations with respect to diets rich in SFAs [32]. Healthy heart effects from olive oil are attributed to its higher contents of monounsaturated fats and its higher ingredients of antioxidants; including: chlorophyll, carotenoids and the polyphenolic compounds, all of these compounds have free radical scavenging ability and protect vitamin $\mathrm{E}$ found in olive oil [33 and 34]. Diet rich in olive oil, has much more favorable effects on lipid profile and lipoproteins compared with coconut oil [35]. The results of lipid profile are in the line with [36] who found that organic olive oil was most efficacious in addressing levels of TC, HDL, LDL, and AI. For all the parameters (except TG and VLDL), organic olive oil not only ameliorated but also prevented changes. In this respect, [37] reported that the intake of phenol rich virgin olive oil decrease total cholesterol TC, LDL and TG levels and substantially increased HDL concentrations. Controlled studies carried out with phenol-rich olive oils al so have shown reductions of blood lipids and also of aortic lesions in hypercholesterolemic rabbits when fed with diets devoid of cholesterol [38]. Simultaneously, olive oil raises the levels of protective HDL cholesterol. Olive oil polyphenols decrease oxidative stress by removing free radicals, the malignant toxic products of oxidation [39]. Bio-phenols contained in virgin olive oil inhibit the cell oxidation of LDL by increasing the mRNA transcription of glutathione enzymes [40].

Our results are line with [41] who found the rats fed on olive oil (1, 2 and $4 \mathrm{ml} /$ day/female rat) were lower than control group for serum urea and creatinine contents. Treated animals were found to have significantly lower urea level compared to control group in adult female rats. Absence of significant difference in blood creatinine level of control and olive oil treated rats implies that despite receiving massive amounts of the oil for a period of 30 days, olive oil did not cause any major defect in renal function in treated rats. But, the results aren't line with [36] who found that, the control group had a low level for serum creatinine for male.

Accordingly, Carajal-Zarrabal et al, [42] found that, GOT and GPT values for control group was decreased in the rest of the groups which gave sucrose (S), olive oil (S-OO) and with avocado oil (S-AO). An increase, not a decrease, in these enzymes is indicative of liver failure in consequence to hepatic metabolic changes [43] was not observed in this case related to an increase in GOT and GPT values. A significant decrease in GOT was observed in the S-OO group. Both olive and avocado oils are recognized as oils with a high percentage of unsaturated fatty acids and a low percentage of saturated.

The results are line with [44] who found the feeding mice on diets containing soybean oil, palm oil, olive oil, sunflower oil, butter or animal fat caused significant increases in calcium concentration in femur bone compared to the control group. Regarding concentrations of phosphorus, the diets only containing soybean oil, olive oil, sunflower oil, butter or animal fat induced significant increases, compared to the control group. A possible influence of olive oil on bone mass inteance and osteoporosis prevention, its results showed that in a Mediterranean diet rich in olive oil for woman had better bone density levels than those on a standard diet [45].Concerning monounsaturated fatty acids, a positive association between BMD and monounsaturated fat, derived mostly from olive oil, has been reported in a sample of Greek men and women [46]. The investigators discussed the influence that vitamin E, abundant in olive oil, exerts on prostaglandin levels and therefore on bone formation and resorption. Furthermore, a dose-response protective effect of oleuropain, an olive oil polyphenol, has been found on bone mass in an experimental in vivo model of bone loss in rats [47]. Accordingly, [48] concluded that olive polyphenols, particularly hydroxytyrosol, prevented bone loss in ovariectomized mice, and suggested olive polyphenols may 
provide insights into the development of tools useful in preventing and treating osteoporosis. Previous research on the impact of fish oils, rich in -3 fatty acids, on skeletal biology has shown consistent and reproducible beneficial effects on bone metabolism and bone/joint diseases, associated in part with downregulating prostaglandin E2 formation, as evidenced in in vivo and in vitro experiments [49].The positive effects of olive oil may be due to its higher contents of MUSFAs, which had a positive associated with bone mineral density [50]. Olive oil prevents the bone loss and improves bone mineral density in rats [34].

\section{Conclusion}

The feeding on olive oils (VOO and EVOO) with or without thyme leaves powder caused to increasing of fertility, improved lipid profile and increasing $\mathrm{Ca}$ and $\mathrm{P}$ of bone contents.

\section{References}

[1] Siemelink, M; Verhoef, A; Dormans, JAM and Span, PN (2002).Dietary fatty acid composition during pregnancy and lactation in the rat programs growth and glucose metabolism in offspring. Diabetologia, 45, 1397 - 1403.

[2] Vickers, MH; Krechowec, SO and Breier, BH (2007).Is later obesity programmed in utero? Curr. Drug Targets, 8(8): 923 934.

[3] Hill, DJ and Duvillie, B (2000). Pancreatic development and adult diabetes.Pediatr Res, 48(3): 269 - 274.

[4] Armitage, JA; Taylor, PD and Poston L (2005). Experimental models of developmental programming consequences of exposure to an energy rich diet during development.J Physiol, 565.1 pp. $3-8$.

[5] Gillman, MW; Rifas-Shiman, SL; Kleinman, K; Oken, E; Rich-Edwards, JW and Taveras, EM (2008). Developmental origins of childhood overweight: Potential Public Health Impact. Obesity (Silver Spring), 16 (7): 1651- 1656.

[6] Omeni, AA; Otamere, HO; Adisa, WA; Osifo, UC; Iyamu, OA; Ediangbe, AP; Akpamu, U and Odiase, DE (2012). A Comparative study on the role of endothelium in aortic vascular response to phenylephrine in normal anddiabetic pregnancy. European Journal of Experimental Biology, 2(6): 1974 - 1979.

[7] Howie, GJ; Sloboda, DM; Kamal, T and Vickers, MH (2009).Maternal nutritional history predicts obesity in adult offspring independent of postnatal diet. J.Physiol, 587, (4), pp. $905-915$.

[8] Moldao-Martins, M; Beirao-da-Costa, S; Neves, C; Cavaleiro, C; Salgueiro, L and Beirao-da-Costa, ML (2004). Olive oil flavored by the essential oils of Mentha x piprita and thymus mastichina L. Food Quality and Preference 15, $447-452$.

[9] Kok FJ and Kromhout D (2004). Atherosclerosis, epidemiological studies on the health effects of a Mediterranean diet. Eur J Nutr.; 43: 2-5.
[10] Covas, MI (2007). Olive oil and cardiovascular system.Pharmacol. Res., 55; 175-186.

[11] Youdim, K.A. and Deans, S.G. (1999). Dietary supplementation of thyme (thymus vulgaris L) essential oil during the life time of the rats its effects on the antioxidant status, in liver, kidney and heart tissues. Mechanisms of Aging and Development. 109:163-175.

[12] Tsimidou, M; Papavergou, E and Boskou, D (1995). Evaluation of oregano antioxidant in mackerel oil. Food Research International 28, 431 - 433.

[13] Ayadi, MA; Grati-Kamoun, N and Attia, H (2009). Physicochemical change and heat stability of extra virgin olive oils flavored by selected Tunisian aromatic plants. Food and Chemical Toxicology, 47; $2613-2619$.

[14] El-Ghousein, S.S. and Al-Beitowi, N.A. (2009). The effect of feeding crushed thyme (Thymus vulgaris L) on growth, blood constituents and gastrointestinal tract and carcass characteristics of broiler chicken. J. Poultry Assoc. 46:100104 .

[15] Reeves, P.G.; Nielsen, F.H. and Fahey, G.C. (1993). AIN-93 purified diets for laboratory rodents: final report of the American Institute of Nutrition Ad HOC writing Committee on the reformulation of the AIN-76 a rodent diet. J Nutr., 123(12): 1939- 1951.

[16] Drury, RA and Wallington, EA (1980). Carton's. Histological Technique. 5thed Oxford Univ.

[17] Allain, CZ; Poon, ZS and Chen, CS (1974): Enzymatic determination of total serum cholesterol. Clin Chem. 20: 470 475 .

[18] Fossati, P and Principle, L (1982). Enzymatic colorimetric method to determination triglyceriods. Clin. Chem. 28: 2077.

[19] Burstein, M (1970): HDL cholesterol determination after separation high density lipoprotein. Lipid. Res. 11: 583.

[20] Essam El-Din, Maha, M (2012). The protective effect of Turnip leaves against oxidative stress induced by high cholesterol diet in adult rats. World Applied Science Journal 20 (1): $154 \quad 163$.

[21] Abbott, RD; Wilson, PW; Kannel, WB and Castelli, WP (1988). High density lipoprotein cholesterol, total cholesterol screening, and myocardial infarction. The Framingham Study. Arteriosclerosis, 8, 207211.

[22] Patton, CJ and Crouch, SR (1977). Enzymatic colorimetric method to determination urea in serum. Anal. Chem. 49: 464.

[23] Bohmer, HBUM (1971): Micro determination of creatinine Clin. Chem. Acta 32: 81-85.

[24] Reitman, S and Frankel, S (1957). A colorimetric method for the determination of serum glutamic oxaloactic and glucanic pyruvic transaminase. Am. J. Clin. Path. 28: 56.

[25] Belfield, A and Golobkrg, DM (1971): Human serum glucose6- phosphate activity conformation of its presence and lack of diagnostic value. Enzyme 12: 561.

[26] AOAC (2000). Official Methods of Analysis of the Association of the Analytical Chemists. 17thed published by the Association of Official Analytical Chemists. Po Box 540. Benjamin Franklin Station Washington DC. 
[27] Arjmand, BH; Alekel, L; Hollis, BW; Amin, D; Sapuntialcis, AS, Guo, P and Pukereja, SC (1996): Dietary soybean prevents bone loss in an ovariectomyed not model of osteoporosis. J. Nut. 126: 161-167.

[28] Snedecor, GW and Cochran WG (1989). Statistical methods. The Lowa State University Press. Ames, Lowe.

[29] Bernardi JR; Escobar R; Ferreira FC and Silveira PP (2012). Fetal and Neonatal Levels of Omega-3: Effects on Neurodevelopment, Nutrition, and Growth. The Scientific World Journal Vol. 2012. http://dx.doi.org/10.1100/2012/202473

[30] Salem, AA (2015). Effect of feeding on olive oil and thyme on pregnancy and lactation periods. Inter. J Nutr. Food Sci., 4(1): $19-28$

[31] Beynen, A.C., J.J. Visser, J.A. Schouten and M.B. Katan, 1987. Cholesterol metabolism in rabbits fed diets containing either corn oil or olive oil. Nutr. Rep. Intern., 35: 111-116.

[32] Hayes, K.C., A. Pronezuk, S. Lindsey and D. Diersen-Schade, 1994. Dietary saturated fatty acids $(12: 0,14: 0,16: 0)$ differ in their impact on plasma cholesterol and lipoproteins in nonhuman primates. Am. J. Clin. Nutr., 53: 491-498.

[33] Morello, J.R., M.J. Motilva, M.J. Tovar and M.P. Romero, 2007. Changes in commercial virgin olive oil during storage, with special emphasis on the phenolic fraction. J. Agric. Food Chem., 85: 357-364.

[34] Puela, C., A. Quintina, A. Agaliasa, J. Matheya, C. Obleda and A. Mazura, 2004. Olive oil and its main phenolic micronutrient (oleuropein) prevent inflammation induced bone loss in the ovariectomised rat. Br. J. Nutr., 92: 119-127.

[35] Mroueh, M; Sakr, J and Daher, C (2009). The effects of oil enriched diet on plasma lipid profile, glucose and coagulation time in rats. PAN Arab. Med. J., 1(4): 25-31.

[36] Al-Amoudi, NS and Abu Araki, HA (2013). Evaluation of vegetable and fish oils diets for the amelioration of diabetes side effects. Journal of Diabetes \& Metabolic Disorders 12:13 -19 .

[37] Gorinstein, S; Leontowicz, HS;Leontowicz, M; Ciz, M; Krzeminski, R; Gralak, M.; Czerwinski, J; Jastrzebski, Z; Trakhtenberg, S; Grigelme-Mignel, N; Soliva -Fortung, R and Marten-Belloso, O (2002): Olive oil improve lipid metabolism and increase antioxidant potential in rats fed diet containing cholesterol. J. Agric. Food Chem. 50: 6102-6108.

[38] Aguilera CM; Ramirez-Tortosa MC; Mesa MD; RamirezTortosa CL and Gil A (2002). Sunflower, virgin-olive and fish oils differentially affect the progression of aortic lesions in rabbits with experimental atherosclerosis. Atherosclerosis, 162: $335-344$.

[39] Fitó M; Cladellas M; de la Torre R; Martí J; Alcántara M; Pujadas-Bastardes M; Marrugat J; Bruguera J; López-Sabater MC; Vila J; Covas MI and members of the SOLOS
Investigators (2005). Antioxidant effect of virgin olive oil in patients with stable coronary heart disease: a randomized, crossover, controlled, clinical trial. Atherosclerosis; 181:14958.

[40] Cicerale S; Conlan XA; Sinclair AJ and Keast RSJ (2009). Chemistry and health of olive oil phenolics. Critical Reviews in Food Science and Nutrition; 49: 218-36.

[41] Nandakumaran M; Al- Shammari M; Al-Sarraf H; Al-Dossery $\mathrm{M}$ and Al-Saleh E(2012). Effect of olive oil administration on some hematologic and metabolic parameters in female rats. Ind. J.Biol. Sci., 18: $1-8$.

[42] Carajal-Zarrabal O; Nolasco-Hipolito C; Aguilar-Uscanga Ma.G; Santiesteban GM; Hayward-Jones PM and BarradaDermitz D Ma (2014). Effect of Dietary Intake of Avocado Oil and Olive Oil on Biochemical Markers of Liver Function in Sucrose-Fed Rats.BioMed Research International, Vol. 2014, 8 pages. http://dx.doi.org/10.1155/2014/595479

[43] Yang, ZH; Miyahara, H; Takeo, J and Katayama, M (2012). Diet high in fat and sucrose induces rapid onset of obesityrelated metabolic syndrome partly through rapid response of genes involved in lipogenesis, insulin signaling and inflammation in mice. Diabetology \& Metabolic Syndrome, vol. 4(1): 32 - 37 .

[44] Rezq, AA; Labib, FA and Attia, AM (2010). Effect of Some Dietary Oils and Fats on Serum Lipid Profile, Calcium Absorption and Bone Mineralization in Mice. Pakistan Journal of Nutrition 9 (7): 643-650.

[45] Kotogionni, MD, Melistas, L; Yanakoulia, M.Malagaris I, Panagiotakos DB and Yiannakouris N (2009). Association between dietary patterns and indices of bone mass in a sample of Mediterranean women. Nutr. 25 (2): 165 - 171.

[46] Trichopoulou A; Georgiou E; Bassiakos Y; Lipworth L; Lagiou P; Proukakis C and Trichopoulos D (1997). Energy intake and monounsaturated fat in relation to bone mineral density among women and men in Greece. Prev. Med. 26: $395-400$

[47] Puel C, Mathey J, Agalias A, Kati-Coulibaly S, Mardon J, Obled C, Davicco MJ, Lebecque P, Horcajada MN, Skaltsounis AL and Coxam V(2006). Doseresponse study of effect of oleuropein, an olive oil polyphenol, in an ovariectomy/inflammation experimental model of bone loss in the rat. Clin. Nutr. 25 (5): $859-868$.

[48] Hagiwara, K; Goto, T; Araki, M; Miyazaki, H and Hagiwara, $\mathrm{H}$ (2011). Olive polyphenol hydroxytyrosol prevents bone loss. Euro. J. Pharmacol., 662: $78-84$.

[49] Watkins BA, Li Y, Lippman HE and Seifert MF. Omega-3 polyunsaturatedfatty acids and skeletal health. Exp Biol Med 2001;226: 485-97.

[50] Trichopoulou, A., A. Naska and T. Costacou, 2002. Dafen III Group Disparities in food habits across Europe. Proc. Nutr. Soc., 61: 553-558. 